\title{
Early School Withdrawals and Underperformance as Indicators of Poor Attention to Learner's Welfare: Botswana in 50 Years of Self-Rule
}

\author{
Boipuso B. Marumo (Corresponding author) \\ University of Botswana \\ 4775 Notwane Rd., Private Bag UB 0022, Gaborone, Botswana \\ E-mail: marumobb@mopipi.ub.bw \\ Nkobi O. Pansiri \\ University of Botswana \\ 4775 Notwane Rd., Private Bag UB 0022, Gaborone, Botswana \\ E-mail: pansirio@mopipi.ub.bw
}

Received: November 6, 2016 Accepted: December 5, 2016

Published: December 8, 2016

doi:10.5296/jei.v2i2.10270 URL: http://dx.doi.org/10.5296/jei.v2i2.10270

\begin{abstract}
September $30^{\text {th }} 2016$ was Botswana's 50th birthday. Botswana, a deeply impoverished country in 1966 was on that day an upper-middle income country in the world rankings. Its education expenditure was one of the highest in the world, at around $9 \%$ of the GDP. It was on record to have provided more than $90 \%$ of universal and free primary education. Guided by the 1977 and 1994 education policies, the country committed itself to the universal declaration that education is a fundamental human right. It adopted a priority of reducing the growing percentages of non-enrolled school age children, let alone working around the clock to increase access to basic education schooling. Despite these good policies and sound financial resources, it has not escaped global challenges of unequal access which has denied some learners the opportunity to complete their education programmes. It also faced huge challenges of low school retention rates, particularly in the basic education programme, that is primary and secondary school systems. This article considers these challenges as critical indicators of lack of attention to learner's welfare in public schools. It argues that in the 50
\end{abstract}


years of self-rule, the basic education program remained trapped in a culture of moral indifference and silent exclusion. The article argues that post $50^{\text {th }}$ birthday, Botswana needs to begin a new chapter, developing an education system that cares about learner's education welfare more than ever before.

Keywords: Learner welfare, Underachievement, Dropouts, Silent exclusion, Moral indifference

\section{Introduction}

Botswana is a landlocked vast country covering an area of 581,730 square kilometers with about two million people in Southern Africa that achieved self-rule in 1966 after eighty-one (81) years as a British Protectorate. It started as a very poor country. Between 1966 and 1999, it experienced the highest average economic growth rate in the world, averaging about $9 \%$ per year, following the discovery of diamonds. Its development was since founded on solid diamond mining coupled with prudent fiscal policies, international financial and technical assistance, and an internationally favourable foreign policy. This positive development saw Botswana being graduated to the current World Bank ranking of an upper-middle income country.

On the $30^{\text {th }}$ September 2016, Botswana celebrated its 50 years of independence. This article is part of an education evaluation effort that explores how a learner's welfare at public or government school system in Botswana has been taken care of over the first 50 years of self-rule. The article uses two critical units of analysis, namely the learner's continued attendance at school and achievement in national examinations in basic education. These are inevitably issues that define the basic quality of any education system.

Like many other nation states, Botswana has adopted its philosophy of development with the framework of Education as a Right for all children. It eventually liberalized education development. Thus, two systems of schools have developed, namely public (government) schools and private (known as English medium) schools. Public schools are non-profit making and government owned. A few are government-aided schools, and these are largely mission schools. Both government and government-aided schools offer free education. The English medium schools are run by companies or individuals, most are profit making ventures, and they charge fees.

In 1977 the country crafted and launched a policy of Education for Kagisano or Education of Nation Building (Republic of Botswana, 1977). This policy was founded on the adopted four national principles of unity, self-reliance, development and democracy. It also guided the school curriculum to focus on these principles. The policy was revised in 1994 to become the Revised National Policy on Education (RNPE) with focus on issues of access, equity and relevance (Republic of Botswana, 1994). On the basis of these issues and guided by the two policies, several reform strategies in policy implementation, education management and classroom practices levels were introduced. As argued elsewhere, education is recognized as a foundation for human fulfillment, peace, sustainable development, economic growth, decent work, gender equality and responsible global citizenship (Taneri \& Engen-Demir, 2011; UNESCO, 2014). Botswana has responded to this gesture very vigorously since 1966 


\section{Macrothink}

in its education policies. In 1997 Botswana adopted a Vision 2016 strategy to build on Education for Kagisano and the RNPE. The Vision introduced a pillar of striving to build "an Educated and Informed Nation". This set yet another goal for which the education system was expected to work towards.

Guided by these three as tools of educational development agenda, we can safely argue that Botswana has achieved its goals in terms of education infrastructure development and widening opportunity for open access to basic education. When Botswana became independent in 1966, it had 251 primary schools, nine (9) secondary schools, two (2) teacher training colleges, one trade school and no university (Keitheile \& Mokubung, 2005). In 2011 there were 811 primary schools in Botswana of which 750 were government schools and 61 were private schools (Monyaku \& Mmereki, 2011a). To date Botswana has 207 public junior secondary schools, 32 senior secondary schools and two (2) unified secondary schools (Statistics Botswana, 2015). Due to this positive development, the enrolment of learners continues to increase in schools annually. It has not been possible to get education statistics from 1966 to 2012. However, Figure 1 is used as an example to illustrate, a continuous growth in primary school enrolment between 2007 and 2012, demonstrating a trend of increasing access to basic education.

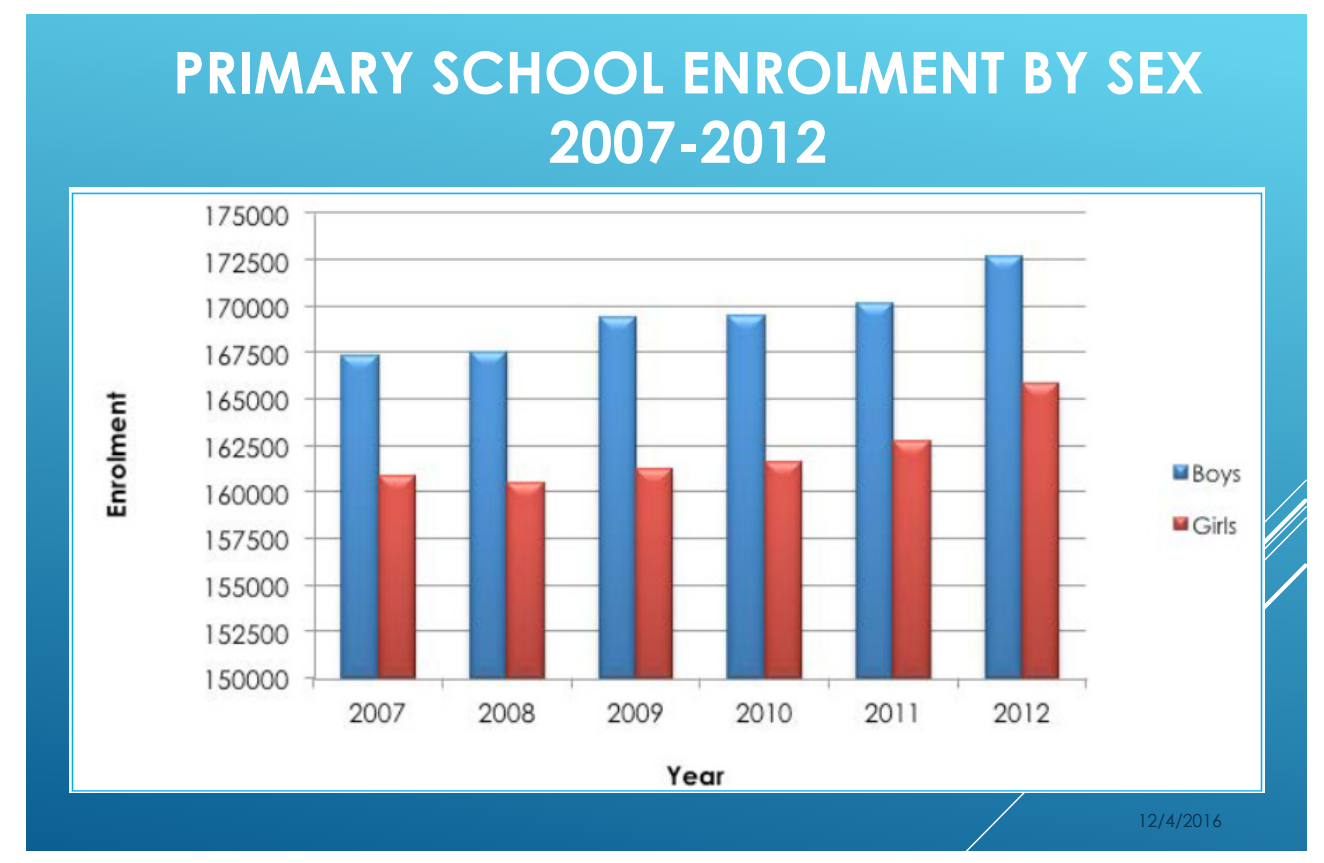

Figure 1. Primary school enrolment growth

Source: Statistics Botswana (2015).

In addition to the increasing enrolments and related numbers of primary schools, 32 primary schools (27 mainstream and 5 special needs) with boarding facilities in remote areas or for special educational needs in peri to urban areas, were constructed in some villages, in the 
interest of addressing the issues of equity and equal opportunity in the provision of the basic education programme. This development reduced the learner-home distances, and schools are more and easily accessible than ever before. Schooling became free in 1980, and feeding programmes were increased to encourage more children to come to school. The country constructed four primary and two secondary colleges of education to accelerate the training of teachers to a diploma qualification and a university to train teachers to a degree qualification. Due to this intensified teacher training, the country now has a surplus of trained teaching personnel. Generally it has been found that Botswana's teacher to learner ratio is $30: 1$, an indication that it is far better in that aspect as compared to other SACMEQ countries (Monyaku \& Mmereki, 2011a). Even compared to neighboring South Africa, Botswana has somewhat better conditions in primary schools in terms of teacher pupil ratio and the proportion of certified teachers (Carnoy et al., 2012).

\section{The Problem Statement}

Unfortunately at 50 years of policy implementation and continued experimentation, indicators show that the basic education academic performance at Primary School Leaving Examination (PSLE), Junior Certificate Examination (JCE) and Botswana General Certificate of Secondary Education (BGCSE) results produced few successful learners. It is here that Pansiri (2011) faults the public school education system as one that got carried away by practices of silent exclusion because the majority of the learners in all the three levels (primary, junior and senior secondary) neither perform well (See Figures $2 \& 3$ ) nor progress to full completion within the system (Tables 1 and 2). The poor performance of the system was echoed by the President of the Republic of Botswana in his 2011 State of the Nation Address. Obviously there are many factors that contribute to the status of the education and performance of learners that the country experiences. This article will only argue that poor attention to learner's welfare in the learning environments experienced in public schools and their classrooms has become a culture of silent exclusion in Botswana's educational development. The authors do not intend to blame teachers, but rather to insist that the visibility and availability of a teacher to a learner is the most motivating tool for a learner's educational success. Poor attention to learners' learning needs or welfare means that teachers maintain a social distance from their learners. The teacher-learner distance may also be influenced by the use of corporal punishment in schools (Tafa, 2002) and the professional behavior of the teachers inside and outside class (Bennell \& Akyeampong, 2007), which may include teacher management, teacher behavior, teacher misconduct, or abuse of students by teachers. In Botswana it has been found that teacher' unprofessional behaviours like absenteeism and sexual relationships with learners are some of the issues affecting learners' attendance and performance in schools (Botswana Federation of Secondary Teachers (BOFESETE), 2003; Moswela \& Marina, 2014). Teachers have been found to use pedagogical approaches that do not promote democratic education (Jotia, 2011; Jotia \& Sithole, 2016). It is therefore argued that, much of the time in the public schools or in the public school classroom, learners are less guided, their academic activities are less monitored; and they are individually less assisted to partake or engage with practical learning activities. As a consequence, the majority of learners are either too disengaged or bored to benefit from 
schooling. In addition, by and large teachers apply pedagogical practices of moral indifference, that is, during the day at school, the majority of the teachers care little about where the learner is, what he or she is doing, or the emotional, psychological and moral challenges he or she faces. Practically, much of the time at school and/or in the classroom, the learner experiences little professional and learning mentorship. It is herein argued that this culture partly explains the continued trends of early school withdrawal and poor academic results at the three levels of the national examinations in the public school system, despite the high record of expenditure that the country has put into education.

\section{Background and Literature}

Generally there are different contributors to the quality of education, and these may include stakeholders (governments, parastatals, private companies, NGO), facilities, administrators, teachers and learners (Taneri \& Engen-Demir, 2011), which are categorized as push/pull factors within school, community and household (Consortium for Research on Educational Access, Transitions and Equity (CREATE), 2008, Rumberger, 2008), alternatively as student, family, school and community related factors (De Witte, Cabus, Thyssen, Groot, Maassen, \& Brink, 2013), and what Nkosana (2013) terms as characteristics of innovation, local factor, external factors, context and culture. Contextual factors affecting educational outcomes are household-level factors such as socio-economic resources (parent education, occupation and wealth) educational resources (availability of schools and teachers) and development level of the region (Smits \& Huisman, 2015). Elsewhere these issues are embedded within zones of exclusion (CREATE, 2011).

Several teachers' behaviours relevant to Botswana's context, may affect learners' attendance, performance and learning in general. For example, researchers have identified problematic teacher behaviours of absenteeism, misconduct like having sexual relationships with learners (BOFSETE, 2003; Bennell \& Akyeampong, 2007), and excessive use of corporal punishment (Tafa, 2002). All these contributors may one way or the other lead to dissatisfaction with the education system by learners. Most importantly learners' dissatisfaction may lead to withdrawal from school or school incompletion. Other sources of dissatisfaction which may lead to learners' withdrawals are bullying, violence, pregnancy, truancy, low academic performance, school/home language mismatch, irrelevant curriculum, poor pedagogical and learning experiences, and inequity, which adversely affect learner's welfare in schools but may not be due to teachers' behaviours. The big question is what school model can be used in order to remedy the problems raised in order to avoid learner dissatisfaction and withdrawal?

Contributors to early school withdrawal and low performance cannot be treated in isolation because they interact with each other in many ways. So, taking all of them aboard may give a good education system model. Also it is worth noting that an education system is only as good as its teachers, and teachers can only shine in the right context, with well-designed curricula and assessment strategies for teaching and learning (UNESCO, 2014). Darling-Hammons (2006) argues that a teacher is the single most powerful variable that determines educational success of a learner. The recipient of all efforts, the learner, must be at the center stage. 
In the life of previous international agenda of Education for All (EFA), and Millennium Development Goals (MDGs); and Education Policy of 1977 and RNPE as well as the era of the Vision 2016 strategy, Botswana has done quite well in terms of education infrastructural development and widening opportunity for open access to educational opportunities to basic education. Botswana is therefore a success story regarding issues of equity and equal opportunity in the provision of the basic education programme. This is a story to celebrate. However, Botswana is no exception to issues of non-completion of school by some learners. The challenges these learners face require attention of improving learning environments. The simplicity of these challenges is usually overstated. It is therefore necessary to apply some theoretical perspectives to interrogate and unpack the challenges, hence the adoption of silent exclusion and moral indifference as the theoretical framework.

\section{Theoretical Perspective: Silent Exclusion and Moral Indifference}

There are different factors which may lead to learners' dissatisfaction with education system and/or schooling. Dissatisfaction could lead to boredom, poor attainment and early withdrawing or dropping out of school. According to a model developed by the Consortium for Research on Educational Access, Transitions and Equity (CREATE), these factors are embedded within zones of exclusion (CREATE, 2011). The zones of exclusion are from 0 to 6. Zone 0 identifies younger children who miss the opportunity for early childhood education. They are excluded from pre-school system. Zone 1 is a classification of children (potential learners) who never attend school. It includes those who could attend existing schools but do not, and those who are excluded by livelihoods, location, civil status, disability, social stigma or other vulnerabilities. Zone 2 includes the majority of children who are excluded after initial entry, who drop out of school and fail to complete a full cycle. In an increasing number of countries these are the largest numbers of out of school children. Zone 3 includes those in school but at risk of dropping out, mostly and obviously as a result of low achievement and poor attendance. These children can be described as "silently excluded" because they experience little to no learning at all. They remain bored in schools or classrooms. Their attendance is characterized by unexplained excuses for absenteeism. Zone 4 categorizes primary school leavers who fail to transit to secondary education as a result of failing to be selected, being unable to afford costs, or located far from a secondary school, or otherwise excluded. Zone 5 includes those learners who withdraw or drop out of secondary school classes. Zone 6 is a category of learners at risk of dropping out from secondary school.

In the case of Botswana various zones of exclusion may apply to some children, as mentioned in the introduction. However, the zone of concern in this study is that of silent exclusion (Zone 3) which includes those in school but is at risk of dropping out because of poor classroom instruction, boredom, learner underachievement, poor attendance, or being over age.

These issues can be attributed to different factors, but it would be unjust to discuss these issues without mentioning the role played by the teacher. In other words, what role can a teacher play to bring about improved learner performance, regular attendance to lessons and improved motivation for learning? Teachers' beliefs, practices and attitudes shape learners' 
learning environment and influence their motivation (OECD, 2009; Pansiri, 2011). A teacher is regarded as learners' role model. It has been indicated elsewhere that teachers' and learners' behavioral problems in the form of absenteeism, skipping class and late coming are somewhat connected (Hungi \& Thuku, 2010; Hungi, 2011). On the learners' side these teacher behavioral problems may lead to underachievement and absenteeism or irregular attendance. These are characteristics of silent exclusion. By extension, if the school head displays the same behavioral challenges, the teachers are likely to emulate his or her undesired professional conduct, and learners would continue to become victims of the unwarranted school culture. The argument here is that, how a teacher teaches, dresses, treats learners in class or conducts him/herself in school determines the level of learners' engagement in and commitment to school activities. Close monitoring of non-attendance (absenteeism, late-coming, and skipping class), pedagogy or direct instruction (adequate pacing, classroom management, clarity of presentation, well-structured lessons, informative and encouraging feedback) have generally been shown to have a positive impact on leaner achievement (OECD, 2009). However the big question for Botswana is, are teachers doing what they are supposed to do? This brings us to issues of moral indifference.

Moral indifference is a perspective where a person knows that an act is morally wrong even though he/she does not disapprove of such acts, except, perhaps, in those cases where he/she is the victim of such acts (Milo, 1981). Moral indifference is when someone simply could not care less about something that they should care about. For example when someone who knows their habits is terrible for the environment but they just don't care and continue with their unacceptable habits or practices.

In Botswana, teachers are pedagogically trained and legitimately employed to effectively develop the learner holistically. They understand the morality of the teaching profession and related ethical conduct. Above everything their mandate includes the duty of care. BOFESETE (2003) alludes to the fact that teachers are expected to conduct themselves in a way that will bring praise, trust, respect and pride to the profession. It has however been found that teachers' knowledge of teacher ethics and professionalism does not necessarily translate into practice (Moswela \& Marina, 2014), and this is a problem that usually leads to learners underperforming and eventually withdrawing. This therefore explains a system that has been trapped into a culture of moral indifference and silent exclusion. The duty of care requires that teachers provide effective instructional activities for each learner, motivates and inspires each learner for effective holistic development. As argued earlier, schools are doing something to the contrary. It is for this reason that Jotia (2011) and Jotia and Sithole (2016) argue that Botswana schools need to shift their focus and promote democratic education in which pedagogies used are seen to be nurturing awareness of the concept of democracy among learners, where learners' voices are heard. With proper delivery of the duty of care, issues of unexplained absenteeism, abuse, boredom, early withdrawal and underachievement in academic engagement are minimal or unheard of. The questions that arise are, Do teachers understand their expected duty of care? Do they move at an adequate learning pace with each learner? Do they provide appropriate learning experiences for each learner? Do teachers worry about bullying, violence, and abuse in their classrooms? In line with the perspective of 
moral indifference in schools and classrooms, it has been argued that poor duty of care is the reason for the many unexplained cases of regular absenteeism, early withdrawals, higher rates of underachievement in school tests and national examinations (Kebalepile, 2014). The issue of teacher behavior such as unaccounted absenteeism was described as an act of moral indifference that contributed to learners' underperformance (Spaull, 2011). Spaull (2011) argues that teachers' frequent absence may also result in learners not attending because of the uncertainty as to whether the teacher is in or not. Receiving low grade in any class learning exercise or test does also influence decisions for early withdrawal. When teachers award marks, there seem to have little regard of the psychological impact of such marks on the individual learners. The authors' observation is that very few people in education are conscious that the failing grades such as $\mathrm{C}$ and $\mathrm{D}$ pass are symbols of humiliation to many of the recipients let alone the highest order of moral indifference.

SE and MI are therefore presented here as critical perspectives that could be used to reflect on the Botswana government education system's achievements and challenges in the past 50 years.

\section{Methodology}

This article is an outcome of a case study that explores school social processes as they unfolded in Botswana basic education in the 50 years of independence. The case study is used to explain the phenomena of early school withdrawal and poor examination results in the context an upper middle income country. In line with Merriam's (1988) argument, this case study is concrete, and contextual. The study was based on the belief that a teacher makes the biggest difference to his or her learners' educational successes more than any other school variable. This understanding is grounded on the fact that studies on value-addition have established that "[learner] achievement gains are much more influenced by a [learner's] assigned teacher than factors such as class size and composition ..." (Darling-Hammond, 2006, p. 19). This case study is in the form of an analytic argument of the possible impact of teachers' visibility and availability to learners at school, hence the question about the degree of attention to learners' welfare in the public school system.

It is a qualitative case study that is based on documentary analysis and connecting with the consistencies and trends in school performances as revealed by officially published national examination results. Bogdan and Biklen (1992, pp. 147-148) have argued that official statistics "can suggest trends in a setting ... provide descriptive information ..." hence the use of officially published reports. This methodological approach affords a highly in-depth analysis of specific empirical issues and official statistics reflecting on specific cases that illustrate the implication of loneliness of learners in schools and/or classrooms. Yin (1989, p. 23) has seen such an approach "an empirical inquiry that investigates a contemporary phenomenon within real life context ... [and] multiple sources of evidence are used". The study deals with real issues in the schools, and here using multiple sources of evidence reported stories and official records.

In this methodological approach, first the general discussion of global dissatisfaction with quality of education is explored. This allowed an interrogation and conceptualization of 
education policies to determine achievements and challenges since 1966. In this way, Botswana's case was examined to identify positive achievement in the 50 years. Following this, a critical exploration of some cases of challenges associated with weak attention that learners receive from their schools and teachers were carried out. This was done through search, identification and interpretation of documented media stories and reports in the 50 years of self-rule. In addition, some selected school leaving examinations results were used as check points to validate contentions about perspectives predominant in schools. Here, the reports from Statistics Botswana were the principal sources of data. Literature from some studies carried out in Botswana was also used to determine how issues of early withdrawal and poor learner achievement emerge from either silent exclusion or moral indifference in the education system.

It is however noted that this methodology is not all embracing. An ethnographic case study would be necessary to illicit behaviors, attitudes and practices among staff in Botswana's schools. Such an approach would document issues and challenges of the education system within specific school contexts much better.

\section{Findings and Discussion}

The desk-based case study explored literature to identify challenges associated with attention to learners' welfare. Some reported cases that suggest that schools were facing issues of Moral Indifference and Silent Exclusion were established. All the cases were found in the public school system in Botswana. The findings are presented and discussed in three thematic areas. These are threat to learners' life, access and early withdrawals, and learner performance in national examinations.

\subsection{Threat to Learner's Life}

Some media reported stories were discovered and briefly described. If the reports are anything to go by, then the story of learner protection in the public school system in the 50 years of self-rule has been a sorry one. Reported incidents revealed that learners have lost lives in schools and school hostels, an indication of the absence of attention to learners' welfare in school systems. The stories are spread throughout the country and are varied in time and nature. Mogapi (2009) and Moronga (2009) presented an incident of an eight-year old primary school girl whose body was found decomposed in the bush after she went missing unnoticed for a week from a boarding primary school. Moipei (2011) reported a case where a person committed suicide and was buried instantly. It was later discovered that this was a 17 year old missing student from a junior secondary school. Tlhaselo (2011) wrote about a case of a student (an 18 year old boy) who was killed by another in a junior secondary school. Pitse (2012) cited warring groups of female students at one senior secondary school who fought viciously and landed a school girl in intensive care at a hospital. Mosikare (2014) reported a case of an 18 year old senior secondary school student who was killed by another in the school. Molefe, Pansiri and Weeks (2009) discussed several issues related to learners who lost lives during educational trips. They identified stories of learners who have become physically disabled in schools through all sorts of abuse, violence and bullying. They cautioned the education system against cases of learners who may be infected 
with all sorts of contagious diseases in schools by persons who were supposed to help them to learn and grow up.

Incidents of a huge number of learners who have been pushed out of the systems by conditions of boarding are found in some studies (Tshireletso, 1997; Polelo, 2005; Republic of Botswana, 2010; Pansiri, 2011). Tafa (2002) argues that although corporal punishment is allowed in the school regulations, teachers abuse the regulations and arbitrarily beat learners unreasonably. The corporal punishment used in schools may inflict pain and sometimes cause bodily injuries. Matsoga (2003) argues that violence was a widespread problem in Botswana schools and that it leads to injuries to learners and teachers alike. In general terms, these actions to some learners may pose a threat to their lives or safety and as such leading to learners being silently excluded.

In the final analysis there are many indicators that learners have been denied the right to education and hence withdrew, and could not complete the basic education. These are some of the current critical challenges in public school system in the basic education programme, and which characterize the magnitude of lack of attention to learner's welfare where it legitimately matters most. Given these cases, the argument here is that in the 50 years of self-rule, Botswana's basic education system has been trapped in the culture and practices of moral indifference, particularly in the schools and classrooms settings. As a result two issues, namely early school withdrawals and poor learner performances continue, resulting in the increasing outcry against the perceived poor education quality. In neighbouring countries such as South Africa a school is seen as more than just a place for every child, but where meaningful access and retention of learners should be guaranteed (Motala et al., 2009).

\subsection{Access and Early School Withdrawals}

In celebrating its success story, Botswana is loud and clear that it has increased opportunities for an open and free access to ten-year basic education programme, thus achieving the Education for All (EFA) Goal No 2 "ensuring that by 2015 all children in difficult circumstances and those belonging to ethnic minority, have access to and complete free and compulsory primary education of good quality" (UNESCO, 2008, p. 14). However there is still the 5 to $10 \%$ of the school going age children that are not accounted for in Botswana. This missing number balloons as one move from the eastern part of Botswana to the western districts of the country. Related to this are early school withdrawals from basic education. Every year primary education loses $1 \%$ through early withdrawals (see Table 1), a category that CREATE (2011) described as Zone 3 of learners who withdraw. 
Table 1. Primary school withdrawals by region (2011-2012)

\begin{tabular}{|l|l|l|l|l|l|l|}
\hline Regions & $\begin{array}{l}\mathbf{2 0 1 0} \\
\text { Enrolment }\end{array}$ & $\begin{array}{l}\mathbf{2 0 1 1} \\
\text { Drop Out }\end{array}$ & $\begin{array}{l}\mathbf{2 0 1 1} \text { Percentage } \\
\text { (\%) Drop Out }\end{array}$ & $\begin{array}{l}\mathbf{2 0 1 1} \\
\text { Enrolment }\end{array}$ & $\begin{array}{l}\mathbf{2 0 1 2} \\
\text { Drop Out }\end{array}$ & $\begin{array}{l}\mathbf{2 0 1 2} \text { Percentage } \\
\text { (\%) Drop Out }\end{array}$ \\
\hline Gantsi & 7118 & 353 & 5 & 7271 & 490 & 6.7 \\
\hline Kgalagadi & 8904 & 133 & 1.5 & 8869 & 146 & 1.6 \\
\hline North West & 28674 & 443 & 1.5 & 29041 & 461 & 1.6 \\
\hline Southern & 42494 & 407 & 1 & 42575 & 503 & 1.2 \\
\hline Kweneng & 46786 & 501 & 1.1 & 47576 & 475 & 1.0 \\
\hline Central & 116804 & 1017 & 0.9 & 117480 & 1028 & 0.9 \\
\hline South East & 37581 & 51 & 0.1 & 36862 & 141 & 0.4 \\
\hline Kgatleng & 14283 & 49 & 0.3 & 14444 & 63 & 0.4 \\
\hline North East & 25300 & 57 & 0.2 & 25572 & 68 & 0.3 \\
\hline Chobe & 3252 & 15 & 0.5 & 3281 & 7 & 0.2 \\
\hline Total & $\mathbf{3 3 1 1 9 6}$ & $\mathbf{3 0 2 6}$ & $\mathbf{0 . 9}$ & $\mathbf{3 3 2 9 7 1}$ & $\mathbf{3 3 8 2}$ & $\mathbf{1 . 0}$ \\
\hline
\end{tabular}

Source: Statistics Botswana (2015).

Students of secondary schools in all the education regions drop out of school each year. Of these early withdrawing students, approximately $25 \%$ come from each Form at the junior secondary level (Form 1 to 3 ). The remaining $25 \%$ of these students withdraw from senior secondary schools (Forms 4 \& 5) (see Table 2).

Table 2. Secondary school withdrawals by sex and form-2012

\begin{tabular}{|l|l|l|l|l|l|l|}
\hline Sex & Form 1 & Form 2 & Form 3 & Form 4 & Form 5 & Total \\
\hline Male & 379 & 323 & 285 & 74 & 121 & 1182 \\
\hline Female & 350 & 390 & 407 & 248 & 262 & 1657 \\
\hline Total & 729 & 713 & 692 & 322 & 383 & 2839 \\
\hline$\%$ & 25.5 & 24.0 & 24.2 & 11.3 & 13.4 & $100 \%$ \\
\hline
\end{tabular}

Source: Adapted from Statistics Botswana (2015). 


\section{Mll Macrothink}

To appreciate this access and retention challenge that Botswana faces, it would help to refer to some research that argues that "students who are engaged emotionally, cognitively and behaviourally are less likely to feel alienated from school" (Jones et al., 2008, p. 8). For learners to be engaged, they need to be in a very good climate, where they feel safe welcomed, treated with respect, and are given opportunities to learn, mature and grow, they will meet their academic potential or learn positive social lessons. Pansiri (2011) has argued that this was missing in most of the Botswana schools, explaining this high number of early school withdrawals.

\subsection{Learner Performance in National Examination}

One major concern is with regards to the poor and/or declining learner performances in the national examinations, namely Primary School Leaving Examinations (PSLE), Junior Certificate Examination (JCE) and Botswana General Certificate of Secondary Education (BGCSE). We will here concentrate on PSLE and JCE, which determine transition rates within the basic education programme. The education statistics show the trend of low performance in PSLE. Figure 2 shows the trend between 2008 and 2012.

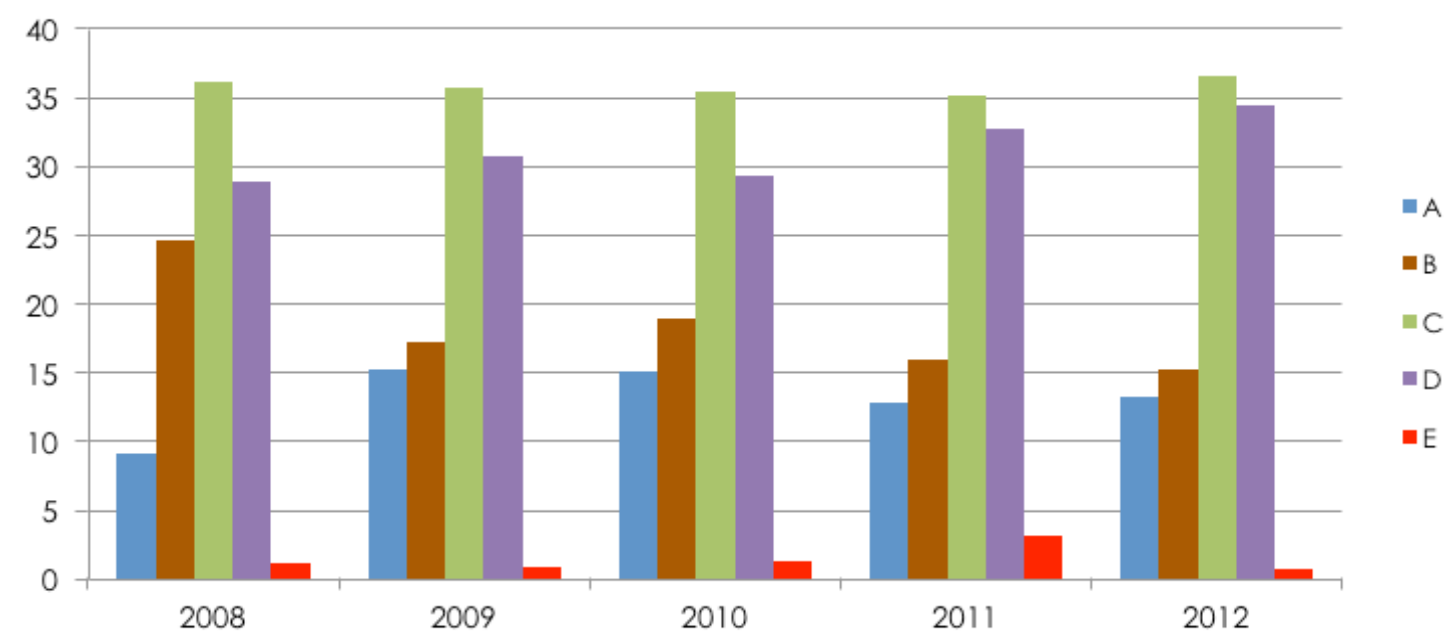

Figure 2. PSLE overall performance, 2008-2012

Source: BEC 2012: PSLE Summary Results 2012.

The public perception in Botswana is that there is a decline in the national examination since 2004. Research has not yet proved or explored these perceptions in-depth. However, both Figures 2 and 3 illustrate a situation where the majority of the learners in both PSLE and JCE consistently obtain pass grades of C and D. As argued earlier, C and D grades couldn't be a more dehumanising record. Elsewhere Pansiri (2012) argues that the C \& D grades are earned disproportionately in the Kgalagadi, Gantsi, North West, Southern and Kweneng (non-Setswana speaking districts). He also put a case that between 2002 and 2004, 88\% of children from schools serving Remote Area Dwellers (RADs) progressed to secondary 
education with pass grades of $\mathrm{C}$ and D. This trend continues beyond 2004. At junior secondary level (see Figure 3), students do not fare any better. Pass rate is higher at $\mathrm{C}$ grade and increases at $\mathrm{D}$ grade. Thus in terms the dominance of $\mathrm{C}$ and $\mathrm{D}$ grades at all levels of basic education, one can safely conclude that for 50 years, the system is predominantly trapped in the culture of low performance.

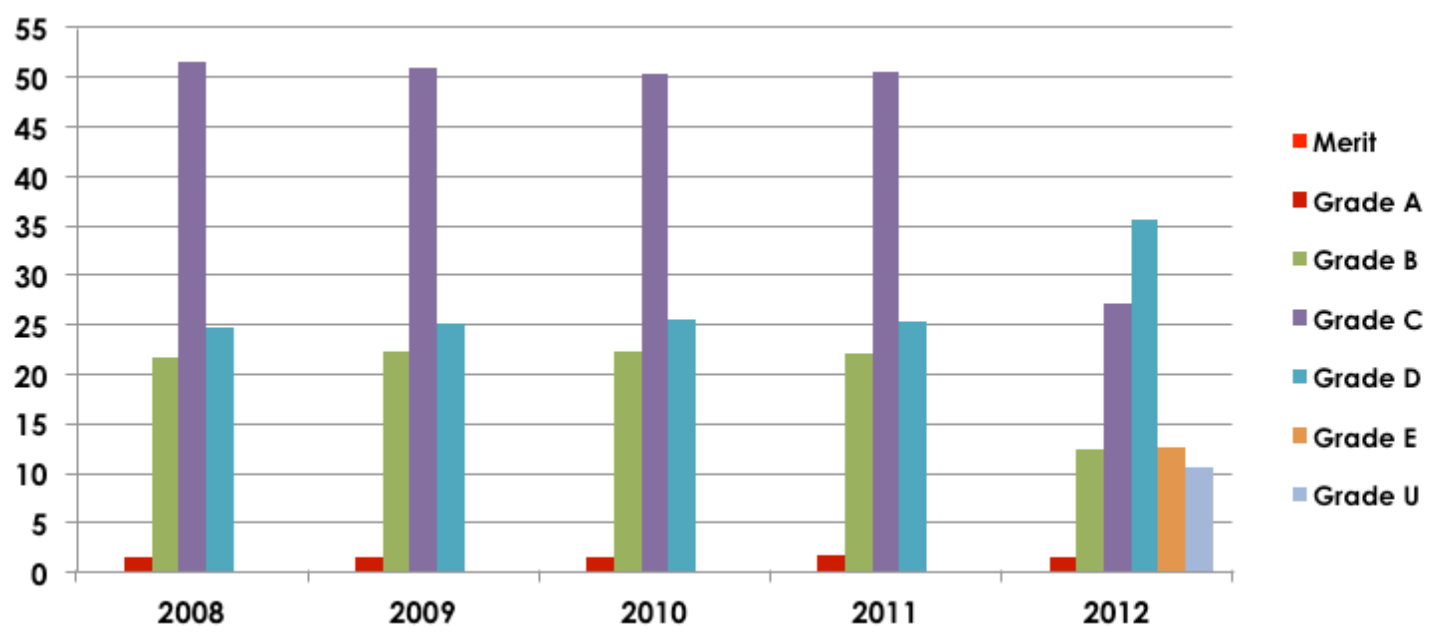

Figure 3. JCE overall performances, 2008-2012

Source: BEC 2008-2012: JCE Summary Results 2012.

Brewster and Fager (2000) argue that learner motivation, classroom engagement and improved attendance are closely connected to increased connectedness between individuals as one aspect of school climate. While this school climate was found to lead to higher achievement, the Botswana situation is a sad one. Teachers continuously describe the issues of high class size, lack of subject specialization at primary school level, hours of work and welfare as some of the causal factors for poor learner performance in national examinations. This may be true. However, research does emphasize the teachers as the most important factor in learners' educational achievement (Darling-Hammond, 2006). They create a school climate. It is argued that a conducive learning environment has a positive impact on learning (Monyaku \& Mmereki, 2011b). In the absence of good school climate, learners will not meet their academic potential. A good school climate is one that guarantees learners safety, effective and productive teacher-learner relationship, positive and supportive learning environment and higher degree of respect for all learners. These factors of good school climate are weak in the Botswana basic education school systems.

\section{Conclusion and Recommendations}

Botswana has done quite well quantitatively, that is, building public schools in almost all settlements and villages. Good initiatives of opening access and attracting learners through programs such as boarding systems, school feeding programmes, and support for RADs have 
yielded little qualitative results because little attention has been paid to improve factors of school climate. There are two major issues which need to be given urgent attention in public schools. These are the culture of silent exclusion and practices that have an appearance of moral indifference. The pervasiveness of the problems gives this appearance of moral indifference on the part of the education system and teachers. Teachers therefore need to be more aware of their moral obligation and roles in the exercise professional responsibility of the 'duty of care'. With the responsibility of duty of care', teachers need to ensure that learners are in suitable, supportive and safe learning spaces at all times in the school systems. Learners need to learn under an adequate system of supervision (largely by the teachers). Public schools have to be led through policies and practices that prevent all sorts of violence, bullying, abuse and disengagement. It has been concluded that where the school climate is not positive, learners usually underperform, their class attendance becomes irregular, and their lack of discipline increases, school safety is compromised, and their chances of disengaging rises. Ultimately, many withdraw. And this is where Botswana basic education system finds itself trapped in attitudes and practices of moral indifference and in a culture of silent exclusion.

The implication of this case study therefore is that Botswana's public school system needs to open a new chapter, work actively at improving school climate. The action may require re-training of teachers to change their attitudes and improve pedagogical skills. It also calls for the revision of policies to increase opportunities of the culture and practices that focus on the duty of care and good citizenship for all in schools. Further research is however, required to ethnographically appreciate the challenges that public schools experience, with a view to reduce attitudes and practices of moral indifference and the culture of silent exclusion.

\section{References}

Bennell, P., \& Akyeampong, K. (2007). Teacher motivation in Sub-Saharan Africa and South Asia. Researching the issues No 71. Department for International Department. Retrieved December 29, 2016, from https://assets.publishing.service.gov.uk/media/57a08be6 40f0b652dd000f9a/ResearchingtheIssuesNo71.pdf

BOFESETE. (2003). Botswana Federation of Secondary School Teachers. Teachers Ethics. Retrieved December 28, 2016, from http://bofesete.org.bw/docs/know_all_about_ bofesete.pdf

Bogdan, R. C., \& Biklen, S. K. (1992). Qualitative Research for Education: An Introduction to Theory and Methods. Boston: Allyn and Bacon.

Brewster, C., \& Fager, J. (2000). Increasing student engagement and motivation: From welfare-on-task to homework. Oregon: North West Regional Laboratory.

Brown, G. T. L. (2006). Conceptions of Curriculum: A framework for Understanding New Zealand's curriculum framework and teachers' opinions. Curriculum Matters, 2, 164-181.

Carnoy, M., Chisholm, L., \& Chilisa, B. (2012). The low Achievement Trap. Comparing Schooling in Botsawna and South Africa. HSRC Press, Capetown. South Africa. Retrieved November 29, 2016, from https://edpolicy.stanford.edu/sites/default/files/publications/low- 
achievement-trap-comparing-schooling-botswana-and-south-africa.pdf

Darling-Hammond, L. (2006). Powerful teacher education: Lessons from exemplary programmes. San Francisco: Jossey-Bass.

De Witte, K., Cabus, S., Thyssen, G., Groot, W., \& Maassen van den Brink, H. (2013). A Critical Review of the Literature on school Dropout. Educational Research Review, 10, 13-28. https://doi.org/10.1016/j.edurev.2013.05.002

Farooq, M. S., Chaundhry, A. H., Shafiq, M., \& Berhanu, G. (2011). Factors Affecting Students Quality of Academic Performance: A case of secondary School Level. Journal of Quality and Technology Management, VII(II), 01-14. Retrieved from http://pu.edu.pk/images/ journal/iqtm/PDF-FILES/01-Factor.pdf on 05/08/2016

Huisman, J., \& Smith, J. (2015). Keeping Children in School: Effects of Household and Context Characteristics on School Dropout in 363 Districts of 30 Developing Countries. Sage Open. https://doi.org/10.1177/2158244015609666

Hungi, N. (2011). Characteristics of school heads and their schools. Working paper number 3 , SACMEQ III working papers.

Hungi, N., \& Thuku, F. W. (2010). Variations in Reading across 14 Sothern African School Systems: Which Factors Matter? International Review of Education, 56, 63-101. https://doi.org/10.1007/s11159-009-9148-x

Jones, M., Yonezawa, S., Mehan, H., \& McClure, L. (2008). School climate and student achievement. California: UC Davis School of Education Centre for Applied Policy in Education.

Jotia, A. (2011). Educating for democtic engagement in Botswana's Democracy. Challenges of promoting Democratic Education. Journal of Social Development in Africa, 26(1), 135-160. https://doi.org/10.4314/jsda.v26i1.68504

Jotia, A., \& Sithole, B. M. (2016). Pragmatizing Democratic Education through Business Education. Countering the Scourge of Diploma Disease. Cogent Education, 3(1), 1-14. https://doi.org/10.1080/2331186X.2016.1189482

Kebalepile, T, (2014). Action Research as panacea for learner's absenteeism in remote area primary schools in Botswana: the case of Kacgae Primary School. Mosenodi Journal, 18 (1 \& 2). $80-93$.

Keitheile, M., \& Mokubung, M. (2005). The SACMEQ II Project in Botswana: A Study of the Conditions of Schooling and Quality of Education. Harare: SACMEQ.

Lunenburg, F. C. (2011). Theorizing about curriculum: Conceptions and Definitions. International Journal of Scholarly Academic Intellectual Diversity, 3(1), 1-6.

Matsoga, J. T. (2003). Curriculum and Instruction. Crime and School Violence in Botswana: The case of Moeding Senior Secondary College ( $\mathrm{PhD}$ Dissertation). College of Education, Ohio University. Retrieved from https://etd.ohiolink.edu/rws_etd/document/get/ohiou107063 
$7898 /$ inline on $28 / 11 / 2016$

Merriam, B. S. (1988). Case Study Research in Education: A Qualitative Approach. San Francisco: Jossey-Bass Publishers.

Mogapi, S. (2009). Could it have been death by tribalism? Botswana Telegraph News (Wednesday, November 18, 2009, p. 7).

Moipei, G. (2011). Sehithwa police investigate suicide. Botswana Daily News (Tuesday, October 25, 2011, No. 201, p. 8).

Molefe, D., Pansiri, O. N., \& Weeks, S. (2009). Issues in Education. Gaborone: Pentagon Publisher.

Molosiwa, S., \& Moswela, B. (2012). Girl-Pupil Dropout in Secondary Schools in Botswana: Influencing factors, Prevalence and Consequences. International Journal of Business and Social Science, 3(7), 265-2.

Monyaku, B., \& Mmereki, O. A. (2011a). Quality of Primary School Inputs in Botswana. SACMEQ III, Policy Brief, Botswana.

Monyaku, B., \& Mmereki, O. A. (2011b). The SACMEQ III Project in Botswana: A Study of the Conditions of Schooling and Quality of Education. SACMEQ, National Reports, Botswana.

Moronga, S. (2009). Young girl's tragic death in the Okavango causes uproar. Botswana Telegraph News (Wednesday, November 18, 2009, Vol. 1, Issue 6).

Mosikare, L. (2014). Student faces murder of fellow student. Mmegi., 31(116), 04.

Moswela, B., \& Marina, G. (2014). Ethics Education Adherence by teacher trainees during practice: A Botswana perspective. Eductional Research and Reviews, 9(7), 197-207.

Motala, S., Dieltiens, V., \& Sayed, Y. (2009). Physical Access to Scooling in South Africa: mapping dropout, repetition and age/grade progression. Comparative Education, 45(2), 251-263. https://doi.org/10.1080/03050060902920948

Nkosana, L. M. (2012). Theoretical Insights into Curriculum Reform in Botswana. International Journal of Scientific Research in Education, 6(1), 68-75.

OECD. (2009). Creating Effective Teaching and Learning Environments: First Results from TALIS. https://doi.org/10.1787/9789264068780-en

Pansiri, O. N. (2011). Silent Exclusion: The Unheard Voices in Remote areas of Botswana. International Journal of Social Sciences, 3(2), 109-118.

Pitse, R. (2012). Violence at school lands girl in ICU. Botswana Sunday Standard Newspaper (p. 3). September 5-15, 2012.

Polelo, M. M. (2005). School Dropout among the Remote Area Dwellers of Botswana: A Socio-Cultural Analysis. Pula: Botswana Journal of African Studies, 19(1), 85-102. 


\section{Macrothink}

Republic of Botswana. (1977). National Policy on Education-Government Paper No. 1 of 1977. Gaborone: Government Printers.

Republic of Botswana. (1994). The Revised National Policy on Education of 1994. Ministry of Education. Gaborone: Government Printer.

Republic of Botswana. (2010). A Report on primary school's hostel desertion. Gaborone: Government Printers.

Rowe, K. (2003). The Importance of Teacher Quality as a Key Determinant of Students Experiences and Outcomes of Schooling. Australian Council for Educational Research. Retrieved October 5, 2015, from http://research.acer.edu.au/research_conference_2003/3/

Rumberger, R. W. (2011). Dropping Out. Why students are drop out of High school and what can be done (pp. 371-380). Harvard University Press. https://doi.org/10.4159/harvard. 9780674063167

Spaull, N. (2011). Primary School Performance in Botswana, Mozambique, Namibia, and South Africa. Working Paper Number 8, In SACMEQ III working Papers.

Statistics Botswana. (2013). Primary Education Statistics 2012. Gaborone: Statistics Botswana.

Statistics Botswana. (2015). Education Statistics Report 2012. Gaborone: Statistics Botswana.

Su, S.-W. (2012). The Various Concepts of Curriculum and the Factors Involved in Curricula Making. Jouranal of Language Teaching and Research, 3(1), 153-158. https://doi.org/ 10.4304/j1tr.3.1.153-158

Tafa, E. M. (2002). Corporal Punishment: The brutal face of Botswana's authoritarian Schools. Educational Review, 54(1), 17-26. https://doi.org/10.1080/00131910120110848

Tlhaselo, J. (2011). Mother blames striking teachers for son's death. The Midweek Sun News (Wednesday, May 18, 2011, p. 3).

Tshireletso, L. (1997). They are the Government's Children: School and Community Relations in Remote Area Dweller Settlement in Kweneng District, Botswana. International Journal of Educational Development, 17(2), 173-188. https://doi.org/10.1016/S0738-0593 (96)00044-2

UNESCO. (2013/14). EFA Global Monitoring Report: TEACING AND LEARNING achieving quality for all.

UNESCO. (2014). Joint Proposal of the EFA steering Committee for Education Post 2015. ED-14/EFA/POST-2015/2 Rev.

World Bank. (2014). Botswana: Skills for Competitiveness and Economic Growth. Washington, DC. (C) World Bank. License: CC BY 3.0 IGO. Retrieved October 5, 2015, from https://openknowledge.worldbank.org/handle/10986/21069 


\section{Macrothink}

Journal of Educational Issues

ISSN 2377-2263

2016, Vol. 2, No. 2

Yin, R. K. (1989). Case Study Research: Design and Methodology (2nd ed.). London: Sage Publishing.

\section{Copyright Disclaimer}

Copyright for this article is retained by the author(s), with first publication rights granted to the journal.

This is an open-access article distributed under the terms and conditions of the Creative Commons Attribution license (http://creativecommons.org/licenses/by/3.0/). 